\title{
Impact local markets on development single- industry towns of mining regions: exploring the case of Khakassia
}

\author{
Tatyana Krasnova ${ }^{1}$, Tatyana Plotnikova $^{2}$, Alexander Pozdnyakov ${ }^{1}$, and Alexander \\ Vilgelm ${ }^{1, *}$ \\ ${ }^{1}$ Khakas state university, Management department, 655017 Abakan, Russia \\ ${ }^{2}$ Siberian federal university, Khakas technical institute, 655017 Abakan, Russia
}

\begin{abstract}
It is well-known that the life quality of monoprophilic territories is largely influenced by city-forming enterprises. The article considers the degree of influence of the city-forming enterprises of the coal industry on the development of agriculture of the industry of mono-profile territories in the region. In particular, the direction of the social vector in the activities of coal mining enterprises with regard to support of the corresponding the life quality in single towns has been revealed. Therefore, the material obtained as a result of the study can be used in the development of social development programs of monoprophilic territories with city-forming enterprises of the coal mining industry. Keywords: economic growth, regional economics, agricultural industry, local markets, social development.
\end{abstract}

\section{Introduction}

The socio-economic development of many territories in which coal mining enterprises are located is largely determined by the policies of these enterprises. Therefore, the regions in which the coal industry enterprises are located are faced with the task of finding effective interaction. For the most part, coal mining enterprises are city-forming in single-industry towns; therefore, the issues of socio-economic development of single-industry territories are important for determining development prospects of coal mining enterprises and strategies for socio-economic development of mining regions.

The coal industry enterprises are entrusted with the tasks of supporting the social sphere in the territory of their presence, in particular with regard to the development of singleindustry settlements (mining towns) [1-3]. Despite the large variety of industries representing the city-forming enterprises of single-industry towns, the coal industry occupies a significant share of up to 9.4 percent and, therefore, has a serious impact on the current state of single-industry settlements.

The strategy of modernization of single-industry towns includes such provisions as: the development of competition, the provision of equal opportunities for the modernization of enterprises, the creation of conditions for the attraction and development of human

*Corresponding author: asvilhelm@gmail.com 
resources, the stimulation of the development of innovative technologies, sustainable and consistent development of integration ties of all types (intra-industry, inter-industry and international) [4].

Integration, based on interconnections and interactions at the sectoral, municipal, regional and interregional levels, contributes to the creation of the most favorable conditions for the long-term functioning of all subjects of integration ties. Therefore, the search for optimal interaction schemes will create the conditions for mining regions' sustainable development at the expense of internal resources. The main objective of the modern approach to the management of coal-mining enterprises located in single-industry areas is the social-oriented regulation of activities in the coal industry. Strengthening the social orientation in the activities of coal mining enterprises contributes to the search for integration ties with various sectors of the economy. In particular, one of the important directions in improving the welfare of the population is the provision of single-industry industrial areas with food [5-9].

Contemporary studies widely acknowledged that influences of mining on reshaping human settlements to promote socio-economic growth remain relatively unexplored in many developing countries [10]. Hence, to take full advantages of their huge economic potential, additional studies are required to understand the reasons accounting for the ineffectiveness of strategies in creating sustainable mining towns.

Diversification of the industrial structure of employment contributes to the alignment of employment cycles, as a conclusion of study [11] in cities the same state or region, the same employment cycle is observed. The ongoing processes of diversification of the industrial structure of employment, according to studies, lead to the diversification of regional centers and peripheral localized markets. The development of local markets for peripheral municipalities is more based on the use of natural resources. Although agglomeration increases with increasing transport costs, development of local markets contributes to an increasing spatial concentration of economic activity [12].

Numerous studies by scientists show that providing the population with agricultural products is one of the determining factors for improving the life quality. Single-industry settlements are located in almost all regions of Russia. Considering single-industry towns with city-forming enterprises of the coal industry, it should be noted that many rural settlements are located near coal mines and quarries, and as a result, affect the ecology and crops. The commissioning of new coal deposits in the Republic of Khakassia during the period over 2015 to 2019 led to a decrease in agricultural land, a decrease in the number of cattle, and a deterioration of the environmental situation in certain regional parts. The social responsibility of the business to the territories located in the zone of its functioning forces the coal mining industries to maintain and develop single-industry territories of coal mining specialization. In this case, agricultural products become most in demand. Consequently, in order to assess the degree of influence of the agricultural industry on raising the standard of living of the population of single-industry territories, it is necessary to determine the factors influencing the livelihoods of a single-industry company.

\section{Materials and Methods}

The article identifies quantitative characteristics of the impact of local markets functioning on the life quality of single-industry territories of the coal mining industry. As a source of information, statistical materials on the socio-economic development of the Republic of Khakassia for 2013-2018 were used.

The studies were conducted using economic and statistical methods, in particular, the correlation and regression analysis. The dynamics of the functioning indicators of single- 
industry towns of the Republic of Khakassia showed an increase in the consumption of agricultural products (Table 1).

Table 1. Indicators of intensity and efficiency of the agricultural production of single-industry towns at coal mining region (the case of Khakassia).

\begin{tabular}{|c|c|c|c|c|c|c|}
\hline Indicators & 2013 & 2014 & 2015 & 2016 & 2017 & 2018 \\
\hline Coal mining, mln roubles & 62492.6 & 63541.4 & 65347.2 & 65547.3 & 67891.4 & 70607.1 \\
\hline $\begin{array}{l}\text { Population single-industry } \\
\text { towns, thousand }\end{array}$ & 160.3 & 159.8 & 159.3 & 159.2 & 158.8 & 158.2 \\
\hline $\begin{array}{l}\text { Income per capita, roubles } \\
\text { per month }\end{array}$ & 17876 & 18385 & 20789 & 21034 & 21209 & 22101 \\
\hline $\begin{array}{c}\text { Meat consumption, kg per } \\
\text { year }\end{array}$ & 68 & 67 & 66 & 65 & 66 & 65 \\
\hline $\begin{array}{l}\text { Milk consumption, litres } \\
\text { per year }\end{array}$ & 259 & 256 & 254 & 252 & 253 & 241 \\
\hline $\begin{array}{c}\text { Bread product } \\
\text { consumption, kg per year }\end{array}$ & 130 & 128 & 128 & 127 & 129 & 127 \\
\hline $\begin{array}{c}\text { Paid household services, } \\
\text { roubles }\end{array}$ & 27949 & 29524 & 30927 & 31230 & 32936 & 33688 \\
\hline $\begin{array}{l}\text { Retail sales per capita, } \\
\text { roubles, total, including }\end{array}$ & 113937 & 123176 & 137261 & 138946 & 147255 & 156273 \\
\hline - food & 56066 & 58970 & 65085 & 63272 & 72585 & 79157 \\
\hline - another & 57871 & 64206 & 72176 & 75674 & 74670 & 77116 \\
\hline Wholesale, mln roubles & 39928.2 & 49390.9 & 70917.7 & 65677.6 & 77273.1 & 85577.8 \\
\hline $\begin{array}{l}\text { Commodity structure of } \\
\text { exports, million US } \\
\text { dollars, total, including }\end{array}$ & 1821.3 & 1909.4 & 1612 & 1530.2 & 1909.7 & 2192.1 \\
\hline $\begin{array}{c}\text { - food products and } \\
\text { agricultural raw materials }\end{array}$ & 0.2 & 0.1 & 0.6 & 2.9 & 1.7 & 2.8 \\
\hline - mineral products & 483.3 & 446.4 & 361 & 359.3 & 673.8 & 990.9 \\
\hline - of which energy products & 475.2 & 446.3 & 359.6 & 322.5 & 599.2 & 812.6 \\
\hline
\end{tabular}

The analysis of statistical data reveals a downward trend in many indicators of social development, but at the same time high rates of growth in coal production persist, for five years the increase was 8.6 per cent. The Republic of Khakassia in the ranking of industrial production index in the field of coal mining takes 3rd place among Siberian regions and 14th place at federal rating. In coal mining sector employed 4 thousand workers (32\%), and since 2017 to 2019 it was decreased around 1.1 per cent at the territories of singleindustry towns, although the local population share increased over $69.1 \%$ to $69.7 \%$, and the rural share decreased from $30.9 \%$ to $30.3 \%$. The share of single-industry towns in gross regional production is 80 per cent of output by sector, fixed capital investment share of Khakassia consist around $23 \%$. There are 9.5 thousand workers or 4 per cent of the economically active population of Khakassia employed at city-forming enterprises. The concentration of economic activity and the local potential of the economy of the Siberian region in single-industry territories, without taking into account the large coal exports share was studied in our previous papers. 
In order to identify the quantitative characteristics of the impact of output by agriculture sector on the growth of socio-economic indicators of single-industry towns in mining regions, a multiple correlation and regression analysis was performed, which includes the development of correlation models and analysis of the results obtained.

Using the information database of statistical data for the Republic of Khakassia, the following variables were investigated: per capita income of the population, population size, employment, fixed capital investment per capita and output by industrial sector.

The lack of evaluative empirical models that determine the degree of influence of agriculture on single-industry settlements with city-forming enterprises of the coal industry makes this study interesting from the point of view of the distribution of the obtained models to other regions.

The purpose of constructing models of the dependence of the socio-economic development of monoprofile territories of coal specialization on the state of agriculture is to identify the effects of localization of the economic activity of local markets.

The fact that the study was carried out for the Siberian region exacerbates the adverse conditions of crop production and animal husbandry: extreme climatic conditions; remoteness of settlements not only from the municipality exercising primary status in a district, but also from each other; poorly developed engineering and transport infrastructure; population decline, especially, young people.

Also, single-industry towns with coal specialization (coal mining) have a high risk of depletion of natural resources, and the agricultural sector in the regional economy is constant, even traditional. Consequently, agricultural production is important for the development of the coal industry.

On the one hand, there is a contradiction arises: the active development of coal mining can gradually supplant agricultural sector of activity due to land reduction and environmental impact.

On the other hand, the development of large business creates the conditions for building the potential of medium and small enterprises. Consequently, the development of local markets requires balanced production and consumption. In this case, single-industry towns are just an example of the dependence of socio-economic development on a city-forming enterprise.

\section{Results and Discussion}

Correlation and regression analysis revealed trends in the links between the output by the primary sector of the Republic of Khakassia (agriculture and mining have limited spatial mobility because of their dependence on land and natural resource inputs) and indicators of the life quality. The indicator of average per capita incomes of the households who live and work in the single-industry town was chosen as an outcome variable, since it most fully reflects the socio-economic situation of the population, including the efficiency of the town-forming coal-mining enterprise. We now discuss each sector of activity in turn.

\subsection{The equations for agriculture production}

According regression analysis, correlation relationships were identified between variables, a matrix of pair correlation coefficients was obtained for this purpose, and regression analysis between indicators was performed on its basis. For the model, indicators with high and medium correlation coefficients were selected. The obtained mathematical model of the connection of the average per capita income of the population with the effective functioning of the agricultural sector has identified the relationship between the socio-economic 
situation of the single-industry towns of the coal industry and the provision of agricultural products to the population of single-industry territories:

$$
y=11,721+0,032 x_{1}+0,521 x_{2}+0,966 x_{3},
$$

where the variable $y$ denotes the income per capita, roubles; $x_{1}$ - output by agriculture sector per capita, mln roubles; $x_{2}$ - grain yield, $\% ; x_{3}$ - investments in agriculture per capita, mln roubles.

The results show that the increase of output by agricultural sector, yields and investments in agriculture affect the income generation of the population, which indicates an increase of the life quality through improved food supply. Table 2 shows the assessment of the closeness, kind of relationships and characteristics the influence of factors.

Table 2. Regression Ratios.

\begin{tabular}{|c|c|c|c|}
\hline Ratios & $\boldsymbol{x}_{\mathbf{1}}$ & $\boldsymbol{x}_{\mathbf{2}}$ & $\boldsymbol{x}_{\mathbf{3}}$ \\
\hline $\begin{array}{c}\text { coefficient of } \\
\text { determination, } \%\end{array}$ & 0.365 & 0.370 & 0.323 \\
\hline $\begin{array}{c}\text { relative standard } \\
\text { deviation }\end{array}$ & 11.045 & 29.374 & 31.247 \\
\hline
\end{tabular}

In overall terms, the coefficients of determination presented in table 2 show the degree of influence of each factor on the average per capita income of the agricultural sector. This result can be attributed to follow factor. Most firms and farmers who consist the set of agriculture sector subjects in Siberia are getting subsidies of federal government, especially, to single-industry towns.

\subsection{Model for the mining industry sector}

The next model is aimed at identifying the relationship between the potential of the mining coal sector in single-industry towns and income per capita:

$$
y=0,661+1,850 x_{1}+0,690 x_{2}+5,612 x_{3}+0,650 x_{4},
$$

where: $y$ - income per capita, roubles; $x_{1}$ - output by mining sector per capita, roubles; $x_{2}-$ proven coal reserves, mln roubles; $x_{3}$ - trucking per capita, mln roubles; $x_{4}$ - investments in mining industry per capita, mln roubles.

Table 3 shows the assessment of the closeness and characteristics the influence of factors.

Table 3. Regression Ratios.

\begin{tabular}{|c|c|c|c|c|}
\hline Ratios & $\boldsymbol{x}_{\mathbf{1}}$ & $\boldsymbol{x}_{\mathbf{2}}$ & $\boldsymbol{x}_{\mathbf{3}}$ & $\boldsymbol{x}_{\mathbf{4}}$ \\
\hline $\begin{array}{c}\text { coefficient of } \\
\text { determination, } \%\end{array}$ & 0,54 & 0,20 & 0,21 & 0,31 \\
\hline $\begin{array}{c}\text { relative standard } \\
\text { deviation }\end{array}$ & 0,58 & 0,07 & 0,41 & 0,37 \\
\hline
\end{tabular}

Thus, the size of agriculture significantly affects the standard of living of the population in single-industry towns and is significant. The results of the assessment show the significance of agriculture productivity and mining potential. Identifying the most promising area for development in regional single-industry towns will contribute to an increase in the concentration of business activity of the subjects of the local market. The 
effectiveness of the interaction of the coal and agricultural industries for the development of the economy of single-industry towns is undeniable. In the mathematical sense, this means an increase in GDP dynamics of the region in forecast periods.

The results presented in table 2 and table 3 are based on the matched sample (sample includes 6 single-industrial areas). We also estimated the model using the full sample by OLS technique. In the case of both models, the estimated coefficients in each of the two performance measures are statistically significant.

\section{Conclusions}

The obtained dependence of the socio-economic indicators single-industry towns on the levels of agricultural output and coal mining suggests the need to consider their mutual influence.

Knowing the trends in the socio-economic indicators of single-industry settlements, it is possible to construct a growth forecast for the main vital signs of a single-industry company associated with an increase in agricultural production at coal mining region. The obtained result is interesting for single-industry areas management to revitalize the agriculture and coal mining sectors. To implement the process of coordinating the interaction of singleindustry territories with agricultural organizations, it is necessary to develop integration development plans.

In particular, studies were conducted for single-industry territories of coal-mining industries in order to identify the social orientation in the activities of coal-mining enterprises in relation to single-industry territories. At the same time, correlations were obtained that determine the influence of the agricultural industry on the life quality of single-industry towns. Consequently, coal mining enterprises need to maintain links with agriculture, including them in the program of social development of the territory.

We would like to thank the Editor and anonymous referees and researchers of T. F. Gorbachev Kuzbass State Technical University for the helpful constructive comments and detailed suggestions.

\section{References}

1. P. Van der Watt, L. Marais, The Extractive Industries and Society, 6, 4, (2019)

2. L. Marais, F. H. McKenzie, L. Deacon, E. Nel, D. Rooyen, J. Land Use Policy, 76, 1 (2018)

3. L. Marais, S. Denoon-Stevens, J. Cloete, Land Use Policy, 93, 1 (2019)

4. S. Harte, J. Grävingholt, H. Pleines, H-H. Schröder, Geschäfte mit der Macht (DTFH, Bremen, 2003)

5. N. Foo, H. Bloch, R. Salim, Resour. Policy, 55, 7 (2018).

6. M. Fujita, P. Krugman, Urban systems and regional development. In The Location of Economic Activity: New Theories and Evidence (Consorcio da Zona, Franca de Vigo, 1994)

7. M. Fujita, P, Krugman, The Spatial Economy (MIT Press, Cambridge, 1997)

8. P. Krugman, Oxford Review of Economic Policy, 14:2, 7-17 (1998)

9. P.P. Combes, T. Mayer, J.F. Thisse, Economic Geography: The Integration of Regions and Nations (Princeton Univ. Press, Princeton, 2008)

10. P. B. Cobbinah, C. Amoako, Cities, 83, 90 (2018) 
11. M. T. Owyang, J. Piger, H. J. Wall, Regional Science and Urban Economics, 43, 2 (2013)

12. T. Tabuchi, J.-F. Thisse, Journal of Urban Economics, 69, 2 (2011) 